\title{
Professor Karol Latowski - plant taxonomist, carpologist and geobotanist
}

\author{
Bogdan Jackowiak* \& Waldemar Żukowski
}

Department of Plant Taxonomy, Faculty of Biology, Adam Mickiewicz University, Umultowska 89, 61-614 Poznań, Poland, *e-mail: bogjack @amu.edu.pl

Among the many eminent botanists who have been profiled in $B R C$, this time we would like to present Professor Karol Latowski, of Adam Mickiewicz University, Poznan, Poland. A good occasion to reflect on his scientific work and achievements is the year of his $75^{\text {th }}$ birthday, which also marks 50 years of his scientific career and sees the holding in Poznan of the $11^{\text {th }}$ International Conference "Synanthropization of Flora and Vegetation".

Karol Latowski was born in Warsaw in 1939. After World War II he lived in Łobżenica, in the Krajenka Lakeland (Pojezierze Krajeńskie) in north-western Poland. In 1957 he graduated from secondary school and began working as a clerk. In 1959-1964 he studied biology at Adam Mickiewicz University, and majored in botany. He began his scientific career at the Department of Pharmaceutical Botany at the Medical University of Poznan, under the guidance of Professor Tadeusz Kowal. It was there that he first became interested in carpology and chemotaxonomy. In 1972 he gained a $\mathrm{PhD}$ in Pharmaceutical Sciences, with a thesis entitled "Research on the fruits and seeds of Central European species of the genus Erysimum L.". Two years later he moved to the newly created Department of Plant Taxonomy at Adam Mickiewicz University. He is still associated with the research team put together there by Professor Waldemar Żukowski. In 1982 he received his habilitation, with a thesis entitled "Taxonomic carpological study of Eurasian species of the genus Lepidium L.”. In 1991, he was awarded the title of Professor by the President of Poland.

Professor Karol Latowski's work includes over 100 publications in the fields of taxonomy, carpology,

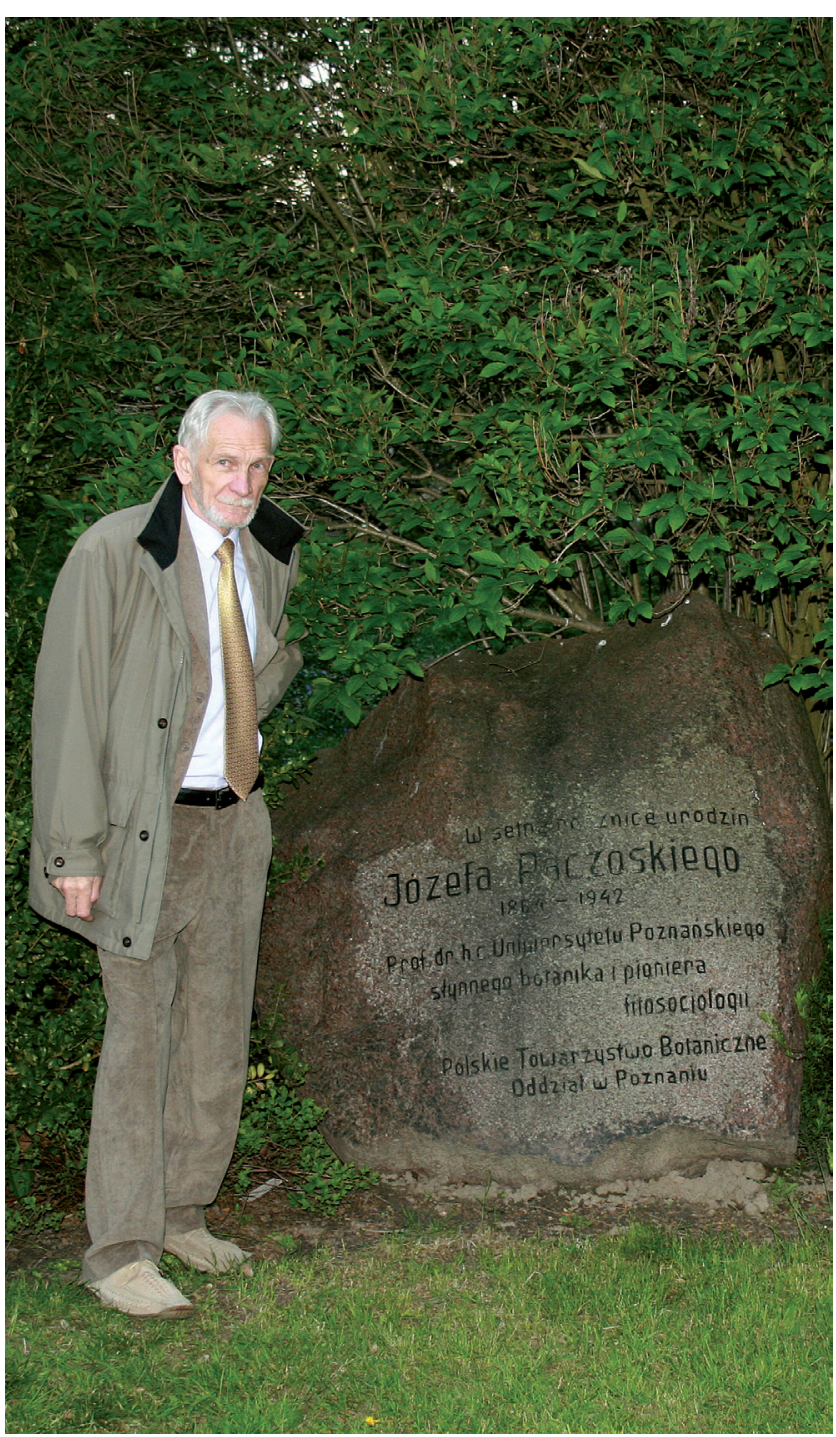

Fig. 1. Professor Karol Latowski (photograph by Z. Celka) 
geobotany and nature conservation. An important place is also taken by his ethnobotanical and bibliographic works. Of particular note also are his publications concerned with Professor Józef Paczoski, one of the most eminent European botanists of the first half of the 20th century.

The main objects of Professor Latowski's research are vascular plants. In his taxonomic and carpological studies he focused on two families: the Apiaceae and Brassicaceae. In this context, particular attention should be drawn to his publications on anatomical diagnostic features in the genera Anthriscus (1969) and Chaerophyllum (1971), as well as the seeds and fruits of Chaerophyllum (1973), Erysimum (1975) and Lepidium (1981a). He described the two last-mentioned genera in the encyclopaedic Flora of Poland (Polish title: Flora Polski, 1985a, 1985b). He reviewed the results of many years of studies of seeds and fruits, partly based on his own rich collection of over 2000 samples, in an article about the development of contemporary carpology in relation to the system of Magnoliophyta (2003). Another example of his investigations of the family Brassicaceae is his co-authored publication on the role of cardenolides in the chemotaxonomic evaluation of selected species of the genera Erysimum, Cheiranthus and Sisymbrium (1978b).

Closely related to his taxonomic works is the Professor's research that aims to document and explain the variation within and between populations of certain species. Using Glaux maritima as an example, his research team tested a hypothesis on a different origin of maritime and inland populations of that halophyte (1981b). Anatomical features of the expansive Puccinellia distans were used to assess possible differences between its natural populations (in salt-marshes) and anthropogenic ones (1985c). In research concerning the genus Glechoma, distinct trends were noticed in the anatomical variation of $G$. hirsuta and $G$. hederacea (1984b), including significant differences between forest and meadow populations of the latter species.

The results of Professor Latowski's studies at the species level are of great value for modern ecology and phytogeography. He investigated declining and endangered species on the one hand, and invasive species on the other. Particularly noteworthy are his works on the current state of the populations of unique components of Polish flora, such as Apium nodiflorum (1985d, 1988a), Apium repens (1988b), Pilularia globulifera (1986/87, 1988c) and Lindernia procumbens (1988d). Important data on the biology and ecology of invasive species were provided by his studies of Anthoxanthum aristatum, a grass species spreading in European cereal fields (1994a, 2005c). An example of his very critical approach to statements perpetuated in the literature is his work that questioned the previously accepted geographical-historical status of Viola odorata in northwestern Poland (1994b).

The detailed taxonomic research conducted by Professor Latowski, as well as the ecological and phytogeographical studies of the above-mentioned species, are based on his excellent knowledge of Central European flora and his extensive field experience, gained in Poland and during his numerous expeditions to the Balkan states and Ukraine. This part of his scientific investigations gave rise to publications of great significance for knowledge of the flora of many regions and habitat types. It also resulted in a rich collection of herbarium specimens, currently kept in the Natural History Collections of the Faculty of Biology at Adam Mickiewicz University. Professor Latowski has also co-authored works on the vascular flora of two Polish national parks: Wielkopolska National Park (1995), and Słońsk nature reserve, now part of Warta River Mouth National Park (2000). He was the first to record in Poland three synanthropic plant species: Aegilops cylindrica Host (1978a), Oxalis dillenii Jacq. (with J. Hantz, 1984a) and Oenothera coronifera Renner (with K. Rostański, 2005d).

Professor Latowski is one of the most active Polish researchers into field weed species and communities, and is a renowned specialist in the flora of railway areas. The results of his long-term research on the distribution of segetal weeds (of arable fields) in the Wielkopolska region (western Poland) were of direct practical importance and have contributed to the optimization of efforts to reduce their impact on crop yields. The floristic and phytosociological data that he collected over several decades have also been used in more comprehensive analyses. For example, the Professor and his research team analysed the species diversity of field weeds depending on soil and agrotechnical conditions (1979), published detailed descriptions of field weed communities developing in winter cereal fields (1990, 1994c), and described transformations in the species composition of the segetal flora of Wielkopolska during the 20th century (1998a). Of great value to the entire community of botanists studying synanthropic flora are the successive editions of his bibliographies of Polish works on the distribution, ecology and biology of segetal weeds (1996, 2001, 2006, 2011).

The Professor's research on plants growing along railway tracks have resulted in many discoveries of synanthropic species, new to the flora of Poland (e.g. 1978a), Bulgaria (1998b) and the Netherlands (mscr.). On this basis, he demonstrated the role played by railway areas as migration routes of alien plant species (2005a), as well as their routes of penetration of extensive woodlands, for instance those of Wielkopolska National Park (2004, 2005b). 
In writing about the Professor's scientific achievements in the field of anthropogenic transformations of plant cover, it is essential also to mention his organizational role within the community of botanists working in this area. For several decades, Professor Latowski has been an active participant in, and frequently a coorganizer of, two series of scientific conferences: (1) the International Conference "Anthropization and Environment of Rural Settlements. Flora and Vegetation" (now "Synanthropization of Flora and Vegetation"), and (2) "Regionalization of Segetal Weeds in Poland". Moreover, for many years he was Vice- dean of the Faculty of Biology at Adam Mickiewicz University, and devoted much of his time to promoting the scientific activities of student organizations.

A figure who has played an important part in the research and life of Professor Karol Latowski is Professor Józef Paczoski, one of the pioneers of the Poznań school of botany, and one of the founders of phytosociology (vegetation science). Focusing here just on the matter of research results, it should be noted that it is thanks to Professor Latowski's exceptional passion and hard work that Paczoski's Flora of the Kherson region (Russian title: Hersonska a flora) has recently been published (2008). Another of Professor Latowski's accomplishments is the publication of the book Considerations on the network of relationships in the plant world (Polish title: Rozważania o sieci powiazań w świecie roślin) (2012). This book includes long extracts from Paczoski's principal works, preceded by a short biography of the distinguished botanist.

In mentioning with great appreciation the commitment of Professor Karol Latowski to reviving the scientific ideas of the founder of phytosociology, we are pleased that he will always be associated with that great man.

\section{Chronological list of selected publications by Professor Karol Latowski}

Kowal T., Latowski K., Macher Z. \& Pic S. 1969. Anatomiczne cechy diagnostyczne leczniczych i trujących gatunków rodzaju Anthriscus Pers. Annales Pharmaceutici 7: 39-59.

Kowal T., Latowski K. \& Macher Z. 1971. Anatomiczne cechy diagnostyczne krajowych gatunków rodzaju Chaerophyllum L. em. Hoffm. Annales Pharmaceutici 9: 57-79.

Kowal T. \& LATOWSKI K. 1973. Morfologiczne i anatomiczne cechy owoców wybranych gatunków rodzaju Chaerophyllum L. em. Hoffm. PTPN Prace Kom. Biol. PTPN 35(7): 1-31.

LATOWsKi K. 1975. Badania nad morfologią i anatomią owoców i nasion środkowo-europejskich gatunków rodzaju Erysimum L. Monogr. Botanicae 49: 5-78.

LAtowski K. 1978a. Aegilops cylindrica Host, nowy gatunek trawy dla flory synantropijnej Polski. Fragm. Flor. Geobot. 24(3): 358-362.

Latowski K., Kortus M. \& Kowalewski Z. 1978b. Rola kardenolidów w ocenie chemotaksonomicznej niektórych gatunków z rodzaju Erysimum, Cheiranthus i Sisymbrium. Fragm. Flor. Geobot. 25(2): 261-267.

LATOWSKi K., SzMAJdA P. \& ŻUKOWSKI W. 1979. Charakterystyka flory pól uprawnych Wielkopolski na przykładzie wybranych punktów badawczych. Bad. Fizjogr. Pol. Zach. seria B-Botanika 31: 65-88.

LATOWSKI K. 1981a. Taksonomiczne studium karpologiczne eurazjatyckich gatunków rodzaju Lepidium L. Wyd. Nauk. UAM, seria Biologia, 23, 105 pp. Poznań.

Żunowski W., Latowski K. \& Klimko M. 1981b. A Comparision of Maritime and Inland of Glaux maritima L. Populations. Fragm. Flor. Geobot. 27(3): 485-499.

Latowski K. \& Hantz J. 1984a. Oxalis dillenii Jacq. - New Species for the Synantropic Flora of Bulgaria. Fragm. Flor. Geobot. 28(4): 549-563.
Żukowski W., Latowski K., Ninova D., Popova M., Cesmedzijev I. \& Kuzmanov B. 1984b. Tendencies in anatomical variation of the genus Glechoma L. as determined by population analysis. Fragm. Flor. Geobot. 28(3): 341-362.

Latowski K. 1985a. Rodzaj Erysimum L. In: A. JASIEwICZ (ed.). Flora Polski, Rośliny naczyniowe, 4: 149-159. PWN, Warszawa-Kraków.

LATOWSKI K. 1985b. Rodzaj Lepidium L. In: A. JASIEWICZ (ed.). Flora Polski, Rośliny naczyniowe, 4: 253-263. PWN, Warszawa-Kraków.

LAtowski K. \& ŻukowsKi W. 1985c. Anatomical characteristic of Puccinellia distans (L.) Parl. in natural and synantropic habitats. Bulletin Soc. Amis Sci. Lett. Ser. D, Sciencies Biologiques PWN, 25: 107-114. Warszawa-Poznań.

Żukowski W., Jackowiak B. \& Latowski K. 1985d. Apium nodiflorum (L.) Lag. w Polsce. Bad. Fizjogr. Pol. Zach., seria B-Botanika 36: 21-34.

Żukowski W., Jackowiak B. \& Latowski K. 1986/87. Występowanie Pilularia globulifera L. nad Jez. Janiszowice na Ziemi Lubuskiej. Fragm. Flor. Geobot. 31-32(1-2): 69-76.

Żukowski W., Jackowiak B. \& Latowski K. 1988a. Apium nodiflorum (L.) Lag. In: A. JASIEwICZ (ed.). Materiały do poznania gatunków rzadkich i zagrożonych Polski. Cz. 1. Fragm. Flor. Geobot. 33(3-4): 280-284.

Żukowski W., Jackowiak B., Latowski K. \& Chmiel J. 1988b. Apium repens (Jacq.) Lag. In: A. JASIEWICZ (ed.). Materiały do poznania gatunków rzadkich i zagrożonych Polski. Cz. 1. Fragm. Flor. Geobot. 33(3-4): 284-290.

ŻUKowski W., JACKOWIAK B. \& LATOWSKi K. 1988c. Pilularia globulifera L. In: A. JASIEWICZ (ed.). Materiały do poznania gatunków rzadkich i zagrożonych Polski. Cz. 1. Fragm. Flor. Geobot. 33(3-4): 441-446. 
Latowski K., ZająC A. \& ZająC M. 1988d. Lindernia procumbens (Krock.) Philcox. In: A. JAsIEwICZ (ed.). Materiały do poznania gatunków rzadkich i zagrożonych Polski. Cz. 1. Fragm. Flor. Geobot. 33(3-4): 416-421.

JACKowiak B., ChMiel J. \& LATOWski K. 1990. Zbiorowiska segetalne zbóż ozimych Wielkopolski. Cz. 1. Bad. Fizjogr. Pol. Zach. seria B-Botanika 40: 107-120.

LATOWSKI K. 1994a. Obserwacje nad biologią tomki ościstej (Anthoxanthum aristatum Boiss. In: S. GRzESIUK (ed.). Przyczyny i źródła zachwaszczenia pól uprawnych, pp. 133-139. Wyd. ART w Olsztynie, Olsztyn-Bęsia.

LAtowsKi K. 1994b. Geographical-Historical status of Viola odorata L. in north-west Poland. In: S. MochnACKÝ \& A. TERPó (eds.). Anthropization and Environment of Rural Settlements. Flora and Vegetation. Proc. of International Conference, Satoraljauhely 22-26 August 1994, pp. 67-74. Olimpia Press, Košice.

JACKowiak B., Chmiel J. \& LATOWsKi K. 1994c. Zbiorowiska segetalne zbóż ozimych Wielkopolski. Cz. II. Bad. Fizjogr. Pol. Zach. seria B-Botanika 43: 105-124.

Żukowski W., Latowski K., Jackowiak B. \& Chmiel J. 1995. Rośliny naczyniowe Wielkopolskiego Parku Narodowego. Prace Zakładu Taksonomii Roślin UAM w Poznaniu 4: 1-229. Bogucki Wyd. Nauk., Poznań.

JACKOWIAK B. \& LATOWSKI K. 1996. Rozmieszczenie, ekologia i biologia chwastów segetalnych. Bibliografia polskich prac do roku 1995. Prace Zakładu Taksonomii Roślin UAM w Poznaniu 5: 1-112. Bogucki Wyd. Nauk., Poznań.

LAtowski K. 1998a. Przemiany składu gatunkowego flory segetalnej Wielkopolski w XX wieku - próba analizy porównawczej. Acta Universitatis Lodziensis, Folia Botanica 13: 73-82.

LATOwsKi K. 1998b. Vascular Plants at the Railway Stations of the Town of Plovdiv (Bulgaria). Thaiszia, Suppl. pp. 27-37.

Chmiel J., Jackowiak B. \& Latowski K. 2000. The vascular plants of the Słońsk Nature Reserve (Western Poland). Biol. Bull. Poznań 37(2): 205-233.

LATOWSKI K. \& JACKOWIAK B. 2001. Rozmieszczenie, ekologia i biologia chwastów segetalnych. Bibliografia polskich prac za lata 1996-2000. Prace Zakładu Taksonomii Roślin UAM w Poznaniu 11: 1-91. Bogucki Wyd. Nauk., Poznań.

LATOWSKi K. 2003. Development of the contemporary carpology against the system of magnoliophyta. Genus, Supplement, pp. 43-49.

LATOWSKi K. 2004. Rośliny naczyniowe terenów kolejowych Wielkopolskiego Parku Narodowego. Cz. I. Skład i właściwości na odcinku Stęszew-Luboń. Morena 11: 61-84.

Latowski K. 2005a. Expansion Rumex confertus Willd. on the railway grounds in Poland. In: S. L. Mosyakin \& M. V. Shevera (eds.). V International Conference Anthropization and Environment of Rural Settlements. Flora and Vegetation, pp. 114-120. M. G. Kholodny Institute of Botany NAS, Kiev.

LATOwSKI K. 2005b. Rośliny naczyniowe terenów kolejowych Wielkopolskiego Parku Narodowego. Cz. II. Skład i właściwości na odcinku Osowa Góra-Puszczykowo. Morena 12: 19-37.

LATOWSKI K. 2005c Ecological-biological reasons and sources of the invasive propensity of Anthoxanthum aristatum Boiss. (Poaceae). Thaiszia 15(1): 143-152.

RostAŃSKI K. \& LATOWSKI K. 2005d. Oenothera coronifera Renner (Onagraceae) a new species in the vascular plant of Poland. Thaiszia 15(1): 143-152.

LATOWSKI K. \& JACKOWIAK B. 2006. Rozmieszczenie, ekologia i biologia chwastów segetalnych. Bibliografia polskich prac za lata 2001-2005. Prace Zakładu Taksonomii Roślin UAM w Poznaniu 16: 1-104.

LAtowski K. \& JACKOWIAK B. 2011. Rozmieszczenie, ekologia i biologia chwastów segetalnych. Bibliografia polskich prac za lata 2006-2010. Prace Zakładu Taksonomii Roślin UAM w Poznaniu 18: 1-130. Wyd. Kontekst.

Paczoski J. 2008. (Latowski K. ed.). Flora Chersonszczyzny, vol. II, 505 pp. Uniwersytet im. Adama Mickiewicza w Poznaniu, Zakład Taksonomii Roślin.

Paczoski J. 2012. (Latowski K. ed.). Rozważania o sieci powiązań w świecie roślin. 352 pp. Poznańskie Towarzystwo Przyjaciół Nauk, Uniwersytet im. Adama Mickiewicza w Poznaniu. 